\title{
Associations Between Short-Term Ambient Particulate Matter Exposure and The Risk of Severe COVID-19
}

\section{Zhong-Qi Li}

Nanjing Medical University

Bi-Lin Tao

Nanjing Medical University

Meng-Yao Zhan

Nanjing Medical University

Zhi-Liang Hu

Nanjing University of Chinese Medicine

Yong-Xiang Yi

Nanjing University of Chinese Medicine

Jian-Ming Wang ( $\nabla$ jmwang@njmu.edu.cn )

Nanjing Medical University https://orcid.org/0000-0002-9151-284X

\section{Research Article}

Keywords: Particulate matter, COVID-19, Severity, Delta variant, Time-series

Posted Date: November 8th, 2021

DOI: https://doi.org/10.21203/rs.3.rs-1035540/v1

License: (1) This work is licensed under a Creative Commons Attribution 4.0 International License. Read Full License 


\section{Abstract \\ Background}

Previous studies have suggested the relation between outdoor air pollution and the onset risk of Corona Virus Disease 2019 (COVID-19). However, there is a lack of data related to the severity of the disease, especially in China.

\section{Methods}

We recruited a group of COVID-19 patients diagnosed in a recent large-scale outbreak caused by Delta variants in eastern China. We collected ambient air pollution data of the same period where the case occurred and applied a generalized linear model (GLM) to analyze the effects of short-term outdoor ambient particulate matter (PM) exposure on the risk of severe COVID-19.

\section{Results}

A total of 476 confirmed adult patients were recruited, of which $42(8.82 \%)$ had a severe illness. With a unit increase in $\mathrm{PM}_{10}$, the risk of severe COVID-19 increased by $47.64 \%$ (95\% confidence interval [CI]: $27.67,70.73)$ at lag $0-14$ days, $65.00 \%(95 \% \mathrm{Cl}: 35.18,101.40)$ at lag $0-21$ days, and $69.44 \%(95 \% \mathrm{Cl}$ : $37.03,109.50)$ at lag 0-28 days, respectively. The association remained significant at lag 0-14 days or 028 days in the multi-pollutant models. With a unit increase in $\mathrm{PM}_{2.5}$, the risk of severe COVID-19 increased by $49.47 \%(95 \% \mathrm{Cl}: 19.61,86.78)$ at lag 0-14 days, $97.61 \%(95 \% \mathrm{Cl}: 45.92,167.60)$ at lag 0-21 days, and $120.27 \%(95 \% \mathrm{Cl}: 56.53,209.98)$ at lag 0-28 days, respectively. The association remained significant at lag 0-21 days or 0-28 days in the multi-pollutant models.

\section{Conclusions}

Our results indicated that short-term exposure to outdoor PM was positively related to the risk of severe COVID-19, and reducing air pollution may contribute to the control of COVID-19.

\section{Background}

In December 2019, the Corona Virus Disease 2019 (COVID-19), caused by the SARS-CoV-2, was first reported in Wuhan and escalated into a global pandemic [1,2]. There is no doubt that COVID-19 has posed a severe threat to global health. Patients with COVID-19 can be categorized into mild, moderate, severe, and critical based on condition. The prognosis of severe and critical patients is poor [3], and the risk factors include older age and hypertension [4]. 
The particulate matter (PM), produced by the combustion of biomass and diesel, and spark-ignited vehicle emissions, is tightly correlated with environmental pollution [5]. In particular, PM with an aerodynamic diameter $\leq 10 \mu \mathrm{m}\left(\mathrm{PM}_{10}\right)$ or $\leq 2.5 \mu \mathrm{m}\left(\mathrm{PM}_{2.5}\right)$ have attracted widespread public attention as they are inhalable $[6,7]$. PM was positively associated with the risk of communicable and noncommunicable diseases [8-10]. A global time-series study showed that short-term PM exposure contributed to an increased cardiovascular and respiratory mortality [11]. Recently, several studies have revealed the possible links between PM exposure and the onset risk of COVID-19 [12, 13]. For example, a multi-city study in China found that for each $10 \mu \mathrm{g} / \mathrm{m}^{3}$ increase in $\mathrm{PM}_{10}$ and $\mathrm{PM}_{2.5}$, the risk of COVID-19 increased by $5 \%$ and $6 \%$, respectively [14]. Another study in Germany showed that every $1 \mu \mathrm{g} / \mathrm{m}^{3}$ increase in $\mathrm{PM}_{10}$ and $\mathrm{PM}_{2.5}$ was associated with 52.38 and 199.46 more confirmed COVID-19 cases per 100,000 inhabitants, respectively [15]. The associations between ambient PM exposure and the onset risk of COVID-19 have been ardently discussed. Nevertheless, studies on the effects of outdoor PM exposure on the severity of COVID-19 are insufficient, notably in China.

On July 20, 2021, Nanjing Lukou International Airport identified nine domestic COVID-19 cases through regular screening. Subsequently, the disease spread rapidly to surrounding cities, resulting in hundreds of confirmed cases in four cities in Jiangsu Province, including Nanjing, Yangzhou, Huaian, and Suqian. The scale of this epidemic in China is second only to the Wuhan epidemic in 2020. The genome sequencing confirmed that the pathogen causing this epidemic was the SARS-CoV-2 B.1.617.2 (Delta) variant, which initially appeared in India [16]. Thus, we collected data of COVID-19 patients identified in this outbreak and ambient air pollution data of the same period where the case occurred, aiming to evaluate the relationships between short-term ambient PM exposure and the risk of COVID-19 severity.

\section{Methods}

\section{Study population}

We collected data of COVID-19 patients admitted to Nanjing Public Health Medical Center from July 20, 2021, to August 17, 2021. All of them came from Nanjing, Yangzhou, Huaian, or Suqian, and were related to the recent outbreak of COVID-19 that originated in Nanjing Lukou international airport. The location of the four cities is shown in Figure 1. The inclusive criteria were as follows: (1) patients aged $\geq 18$ years; (2) they were infected with the Delta variant. We collected general characteristics of patients including city, sex, age, current or past hypertension (yes or no), current or past diabetes (yes or no), current or past heart disease (yes or no), current or past carcinoma (yes or no), current or past COPD (yes or no), current or past asthma (yes or no), current or past autoimmune disease (yes or no), vaccination status (unvaccinated, partially vaccinated, or fully vaccinated), and days between onset and hospitalization. Patients were defined as fully vaccinated if they had received two doses of vaccination with the interval between the two doses $\geq 21$ days and the onset date was $\geq 14$ days from the second dose [17]. 
The diagnosis and classification of COVID-19 referred to the "Guidelines for Diagnosis and Treatment of COVID-19 (Trial Eighth Edition)" issued by the National Health Commission (http://www.nhc.gov.cn/). Patients were categorized as mild, moderate, severe, and critical based on the condition. In the current study, we combined severe and critical together and named them as severe.

\section{Air pollution data}

We extracted daily concentration data of six ambient air pollutants, including $\mathrm{PM}_{10}, \mathrm{PM}_{2.5}, \mathrm{SO}_{2}, \mathrm{NO}_{2}, \mathrm{CO}$, and $\mathrm{O}_{3}$ (the concentration of $\mathrm{O}_{3}$ was the maximum 8-hour moving average) in four cities between June 15,2021 , and August 15, 2021, from National urban air quality real-time release platform (http://106.37.208.233:20035/). Except that the unit of CO concentration was $\mathrm{mg} / \mathrm{m}^{3}$, the concentration of other pollutants was $\mu \mathrm{g} / \mathrm{m}^{3}$.

\section{Statistical analysis}

We applied the generalized linear model (GLM) with the logit connect function to estimate the effects of short-term PM exposure on the severity of COVID-19. The GLM has been widely used in exploring the associations between air pollutants and health outcomes $[18,19]$. Covariates adjusted in the model included city, sex, age, current or past hypertension, current or past diabetes, current or past heart disease, current or past carcinoma, current or past COPD, current or past asthma, current or past autoimmune disease, vaccination status, and days between onset and hospitalization. Previous studies showed that PM exposure might have lag effects on health $[20,21]$. Thus, we calculated the moving average concentration of PM to describe personal PM exposure level according to the onset date of COVID-19 and place of residence $[20,22]$. For instance, if the onset date was August 1 , we extracted the daily average concentration of PM in the same place from July 4 to August 1 . Then, we calculated the average concentration from July 25 to August 1 as the 8-day moving average, from July 18 to August 1 as the 15day moving average, and from July 4 to August 1 as the 29-day moving average. We used four different lag times, including lag 0-7 days (8-day moving average), lag 0-14 days (15-day moving average), lag 021 days (22-day moving average), and lag 0-28 days (29-day moving average) [22, 23]. The strength of associaiton was expressed as the changes in the risk of severe COVID-19 and their $95 \%$ confidence intervals (Cls) for a unit increase in PM concentration.

We conducted two sensitivity analyses to examine the robustness of the relationships between PM exposure and severe COVID-19. First, as mentioned above, we estimated the association at different lag times. Second, we adjusted other air pollutants to construct multi-pollutant models. We used the Spearman rank correlation test to evaluate the correlation between air pollutants. Only pollutants with $|r|$ $<0.7$ could enter into the multi-pollutant models to address the multiple collinearity problem [24]. Moreover, in order to ensure the comparability of the models, only pollutants with all $|r|<0.7$ at four lag times were entered into the multi-pollutant models. For example, if the $|\mathrm{r}|$ between $\mathrm{SO}_{2}$ and $\mathrm{PM}_{10}$ were all $<0.7$ at four lag times, while the $|r|$ between $\mathrm{NO}_{2}$ and $\mathrm{PM}_{10}$ were $<0.7$ at only three lag times, $\mathrm{SO}_{2}$ could enter into the multi-pollutant models while $\mathrm{NO}_{2}$ could not. 
Additionally, we performed a subgroup analysis to explore whether the effects of PM exposure on the risk of severe COVID-19 were modified by sex or age. The difference in effects between subgroups was examined by the following formula: $\left|\beta_{1}-\beta_{2}\right| / \sqrt{S E_{1}{ }^{2}+S E_{2}{ }^{2}}$, where $\beta_{1}$ and $\beta_{2}$ were the estimated effects, and $S E_{1}$ and $S E_{2}$ were their standard errors. The difference was considered to be statistically significant if the value was $>1.96$ [25]. All analyses were performed using R software version 4.0.4 (https://www.r-project.org/). The significance level was 0.05 .

\section{Results}

\section{Characteristics of the patients}

A total of 533 COVID-19 patients were admitted, and 476 patients that met the inclusion criteria were included in the current study, of which 273 (57.35\%) came from Yangzhou, 189 (39.71\%) came from Nanjing, 12 (2.52\%) came from Huaian, and 2 (0.42\%) came from Suqian (Figure 1). Among them, 42 (8.82\%) were classified as severe, 289 (60.71\%) were females, 298 (62.61\%) were 18-59 years old, 109 $(22.90 \%)$ had hypertension, $43(9.03 \%)$ had diabetes, 21 (4.41\%) had heart disease, $11(2.31 \%)$ had carcinoma, $3(0.63 \%)$ had COPD, $9(1.89 \%)$ had asthma, $5(1.05 \%)$ had autoimmune disease, and 151 (31.72\%) patients were fully vaccinated.

\section{Concentration of $\mathrm{PM}_{10}$ and $\mathrm{PM}_{2.5}$ in four cities}

Between June 15, 2021, and August 15, 2021, the median (interquartile range) concentration of $\mathrm{PM}_{10}$ was $34.00(20.25) \mu \mathrm{g} / \mathrm{m}^{3}$ in Yangzhou, 31.50 (17.25) $\mu \mathrm{g} / \mathrm{m}^{3}$ in Nanjing, 28.00 (19.75) $\mu \mathrm{g} / \mathrm{m}^{3}$ in Huaian, and $34.00(20.50) \mu \mathrm{g} / \mathrm{m}^{3}$ in Suqian (Table 2). The median (interquartile range) concentration of $\mathrm{PM}_{2.5}$ was $17.50(13.25) \mu \mathrm{g} / \mathrm{m}^{3}$ in Yangzhou, 15.50 (12.00) $\mathrm{gg} / \mathrm{m}^{3}$ in Nanjing, 16.00 (11.25) $\mu \mathrm{g} / \mathrm{m}^{3}$ in Huaian, and $17.50(12.25) \mu \mathrm{g} / \mathrm{m}^{3}$ in Suqian (Table 2). 
Table 1

Characteristics of 476 COVID-19 patients with or without severe illness.

\begin{tabular}{|c|c|c|c|}
\hline \multirow[t]{2}{*}{ Characteristics } & Non-severe illness & Severe illness & \multirow[t]{2}{*}{$P^{a}$} \\
\hline & $\begin{array}{l}\mathrm{n}(\%) \text { or median } \\
\text { (interquartile range) }\end{array}$ & $\begin{array}{l}\mathrm{n}(\%) \text { or median } \\
\text { (interquartile range) }\end{array}$ & \\
\hline Gender & & & 0.247 \\
\hline Male & $167(89.30)$ & $20(10.70)$ & \\
\hline Female & 267 (92.39) & $22(7.61)$ & \\
\hline Age group (years) & & & $<0.001$ \\
\hline $18-59$ & $286(95.97)$ & $12(4.03)$ & \\
\hline$\geq 60$ & $148(83.15)$ & $30(16.85)$ & \\
\hline \multicolumn{4}{|l|}{ Medical conditions } \\
\hline Hypertension & $94(86.24)$ & 15 (13.76) & 0.038 \\
\hline Diabetes & $35(81.40)$ & $8(18.60)$ & 0.037 \\
\hline Heart disease & $16(76.19)$ & $5(23.81)$ & 0.037 \\
\hline Carcinoma & $9(81.82)$ & $2(18.18)$ & 0.252 \\
\hline COPD & $1(33.33)$ & $2(66.67)$ & 0.022 \\
\hline Asthma & $8(88.89)$ & $1(11.11)$ & 0.568 \\
\hline Autoimmune disease & $4(80.00)$ & $1(20.00)$ & 0.371 \\
\hline Vaccination status & & & $<0.001$ \\
\hline Unvaccinated & $114(84.44)$ & $21(15.56)$ & \\
\hline Partially vaccinated & $170(89.47)$ & $20(10.53)$ & \\
\hline Fully vaccinated & 150 (99.34) & $1(0.66)$ & \\
\hline $\begin{array}{l}\text { Days between onset and } \\
\text { hospitalization }\end{array}$ & $3.00(4.00)$ & $3.00(3.00)$ & 0.152 \\
\hline
\end{tabular}


Table 2

Daily average concentration of air pollutants in four cities in Jiangsu between June 15, 2021 and August 15, 2021.

\begin{tabular}{|c|c|c|c|c|c|c|c|}
\hline City & Air pollutant & Minimum & $Q_{25}$ & Median & Mean & $Q_{75}$ & Maximum \\
\hline \multirow[t]{6}{*}{ Yangzhou } & $\mathrm{PM}_{10}\left(\mu \mathrm{g} / \mathrm{m}^{3}\right)$ & 8.00 & 27.50 & 34.00 & 37.35 & 47.75 & 82.00 \\
\hline & $\mathrm{PM}_{2.5}\left(\mu \mathrm{g} / \mathrm{m}^{3}\right)$ & 5.00 & 13.00 & 17.50 & 19.39 & 26.25 & 38.00 \\
\hline & $\mathrm{SO}_{2}\left(\mu \mathrm{g} / \mathrm{m}^{3}\right)$ & 7.00 & 9.00 & 9.00 & 9.89 & 11.00 & 14.00 \\
\hline & $\mathrm{NO}_{2}\left(\mu \mathrm{g} / \mathrm{m}^{3}\right)$ & 4.00 & 10.00 & 18.00 & 18.03 & 24.25 & 38.00 \\
\hline & $\mathrm{CO}\left(\mathrm{mg} / \mathrm{m}^{3}\right)$ & 0.30 & 0.40 & 0.50 & 0.51 & 0.60 & 0.90 \\
\hline & $\mathrm{O}_{3}\left(\mu \mathrm{g} / \mathrm{m}^{3}\right)$ & 51.00 & 81.75 & 107.00 & 120.55 & 161.25 & 268.00 \\
\hline \multirow[t]{6}{*}{ Nanjing } & $\mathrm{PM}_{10}\left(\mu \mathrm{g} / \mathrm{m}^{3}\right)$ & 6.00 & 24.75 & 31.50 & 33.63 & 42.00 & 71.00 \\
\hline & $\mathrm{PM}_{2.5}\left(\mu \mathrm{g} / \mathrm{m}^{3}\right)$ & 3.00 & 11.00 & 15.50 & 17.68 & 23.00 & 47.00 \\
\hline & $\mathrm{SO}_{2}\left(\mu \mathrm{g} / \mathrm{m}^{3}\right)$ & 3.00 & 5.00 & 5.00 & 5.16 & 6.00 & 7.00 \\
\hline & $\mathrm{NO}_{2}\left(\mu \mathrm{g} / \mathrm{m}^{3}\right)$ & 6.00 & 14.75 & 18.50 & 18.92 & 24.25 & 32.00 \\
\hline & $\mathrm{co}\left(\mathrm{mg} / \mathrm{m}^{3}\right)$ & 0.30 & 0.48 & 0.50 & 0.56 & 0.70 & 0.90 \\
\hline & $\mathrm{O}_{3}\left(\mu \mathrm{g} / \mathrm{m}^{3}\right)$ & 48.00 & 84.25 & 105.50 & 116.77 & 146.75 & 207.00 \\
\hline \multirow[t]{6}{*}{ Huaian } & $\mathrm{PM}_{10}\left(\mu \mathrm{g} / \mathrm{m}^{3}\right)$ & 8.00 & 20.75 & 28.00 & 30.44 & 40.50 & 68.00 \\
\hline & $\mathrm{PM}_{2.5}\left(\mu \mathrm{g} / \mathrm{m}^{3}\right)$ & 6.00 & 12.00 & 16.00 & 18.34 & 23.25 & 40.00 \\
\hline & $\mathrm{SO}_{2}\left(\mu \mathrm{g} / \mathrm{m}^{3}\right)$ & 3.00 & 4.00 & 4.00 & 4.37 & 5.00 & 8.00 \\
\hline & $\mathrm{NO}_{2}\left(\mu \mathrm{g} / \mathrm{m}^{3}\right)$ & 4.00 & 8.00 & 10.00 & 12.00 & 13.25 & 35.00 \\
\hline & $\mathrm{co}\left(\mathrm{mg} / \mathrm{m}^{3}\right)$ & 0.20 & 0.20 & 0.40 & 0.36 & 0.43 & 1.00 \\
\hline & $\mathrm{O}_{3}\left(\mu \mathrm{g} / \mathrm{m}^{3}\right)$ & 42.00 & 72.75 & 103.50 & 108.76 & 133.00 & 231.00 \\
\hline \multirow[t]{2}{*}{ Suqian } & $\mathrm{PM}_{10}\left(\mu \mathrm{g} / \mathrm{m}^{3}\right)$ & 9.00 & 26.00 & 34.00 & 36.63 & 46.50 & 78.00 \\
\hline & $\mathrm{PM}_{2.5}\left(\mu \mathrm{g} / \mathrm{m}^{3}\right)$ & 5.00 & 13.00 & 17.50 & 18.65 & 25.25 & 40.00 \\
\hline
\end{tabular}




\begin{tabular}{|cccccccc|}
\hline City & Air pollutant & Minimum & $\mathbf{Q}_{\mathbf{2 5}}$ & Median & Mean & $\mathbf{Q}_{\mathbf{7 5}}$ & Maximum \\
\hline $\mathrm{SO}_{2}\left(\mu \mathrm{g} / \mathrm{m}^{3}\right)$ & 2.00 & 4.00 & 5.00 & 5.16 & 6.00 & 9.00 \\
\hline $\mathrm{NO}_{2}\left(\mu \mathrm{g} / \mathrm{m}^{3}\right)$ & 2.00 & 6.00 & 9.00 & 10.26 & 13.25 & 25.00 \\
\hline $\mathrm{CO}\left(\mathrm{mg} / \mathrm{m}^{3}\right)$ & 0.30 & 0.40 & 0.40 & 0.47 & 0.60 & 0.90 \\
$\mathrm{O}_{3}\left(\mu \mathrm{g} / \mathrm{m}^{3}\right)$ & 44.00 & 84.75 & 108.50 & 116.85 & 145.25 & 259.00 \\
\hline
\end{tabular}

\section{$\mathrm{PM}_{10}$ and severe COVID-19}

In the single-pollutant models, $\mathrm{PM}_{10}$ was positively related to the risk of severe COVID-19 at lag 0-14 days, lag 0-21 days, and lag 0-28 days. The maximum effect was at lag 0-28 days. For a unit increase in $\mathrm{PM}_{10}$, the risk of severe COVID-19 increased by $69.44 \%(95 \% \mathrm{Cl}: 37.03,109.50)$ (Table 3$)$.

Table 3

Changes in the risk of severe COVID-19 and their $95 \%$ Cls for a unit increase in the concentration of particulate matter.

\begin{tabular}{|c|c|c|c|c|}
\hline \multirow[t]{2}{*}{ Lag time } & \multicolumn{2}{|l|}{$\mathrm{PM}_{10}$} & \multicolumn{2}{|l|}{$\mathrm{PM}_{2.5}$} \\
\hline & $\begin{array}{l}\text { Single-pollutant } \\
\text { model }^{\mathrm{a}}\end{array}$ & $\begin{array}{l}\text { Multi-pollutant } \\
\text { model }^{b}\end{array}$ & $\begin{array}{l}\text { Single-pollutant } \\
\text { model }^{\mathrm{a}}\end{array}$ & $\begin{array}{l}\text { Multi-pollutant } \\
\text { model }^{b}\end{array}$ \\
\hline $\begin{array}{l}\text { Lag } 0-7 \\
\text { days }\end{array}$ & $3.64(-4.29,12.22)$ & $\begin{array}{l}7.44(-6.25 \\
23.13)\end{array}$ & $\begin{array}{l}-7.69(-18.91 \\
5.08)\end{array}$ & $\begin{array}{l}-12.61(-24.03 \\
0.53)\end{array}$ \\
\hline $\begin{array}{l}\text { Lag 0-14 } \\
\text { days }\end{array}$ & $\begin{array}{l}47.64(27.67 \\
70.73)\end{array}$ & $\begin{array}{l}43.02(5.26 \\
94.32)\end{array}$ & $\begin{array}{l}49.47(19.61, \\
86.78)\end{array}$ & $\begin{array}{l}15.33(-12.14 \\
51.38)\end{array}$ \\
\hline $\begin{array}{l}\text { Lag 0-21 } \\
\text { days }\end{array}$ & $\begin{array}{l}65.00(35.18 \\
101.40)\end{array}$ & $\begin{array}{l}10.02(-33.65 \\
82.42)\end{array}$ & $\begin{array}{l}97.61(45.92 \\
167.60)\end{array}$ & $\begin{array}{l}69.08(22.12 \\
134.10)\end{array}$ \\
\hline $\begin{array}{l}\text { Lag 0-28 } \\
\text { days }\end{array}$ & $\begin{array}{l}69.44(37.03 \\
109.50)\end{array}$ & $\begin{array}{l}124.99(14.22 \\
343.21)\end{array}$ & $\begin{array}{l}120.27(56.53 \\
209.98)\end{array}$ & $\begin{array}{l}104.79(28.57 \\
226.19)\end{array}$ \\
\hline \multicolumn{5}{|c|}{$\begin{array}{l}\text { a. Adjusted for city, sex, age, current or past hypertension, current or past diabetes, current or past } \\
\text { heart disease, current or past carcinoma, current or past COPD, current or past asthma, current or pas } \\
\text { autoimmune disease, vaccination status, and days between onset and hospitalization. }\end{array}$} \\
\hline
\end{tabular}

In the multi-pollutant models, $\mathrm{PM}_{10}$ was positively correlated with the risk of severe COVID-19 at lag 0-14 days and lag 0-28 days. The maximum effect was also at lag 0-28 days. For a unit increase in $\mathrm{PM}_{10}$, the risk of severe COVID-19 increased by $124.99 \%$ (95\% Cl: 14.22, 343.21) (Table 3).

\section{$\mathrm{PM}_{2.5}$ and severe COVID-19}


In the single-pollutant models, $\mathrm{PM}_{2.5}$ was positively related to the risk of severe COVID-19 at lag 0-14 days, lag 0-21 days, and lag 0-28 days. The maximum effect was at lag 0-28 days. For a unit increase in $\mathrm{PM}_{2.5}$, the risk of severe COVID-19 increased by $120.27 \%$ (95\% Cl: $\left.56.53,209.98\right)$ (Table 3$)$.

In the multi-pollutant models, $\mathrm{PM}_{2.5}$ was positively correlated with the risk of severe COVID-19 at lag 0-21 days and lag 0-28 days. The maximum effect was also at lag 0-28 days. For a unit increase in $\mathrm{PM}_{2.5}$, the risk of severe COVID-19 increased by $104.79 \%$ (95\% Cl: 28.57, 226.19) (Table 3).

\section{Subgroup analysis}

The associations between $\mathrm{PM}_{10}$ and the risk of severe COVID-19 remained significant in different gender or age groups at lag 0-14 days, lag 0-21 days, and lag 0-28 days. The maximum effect was observed at lag 0-28 days. For a unit increase in $\mathrm{PM}_{10}$, the risk of severe COVID-19 increased by $132.03 \%(95 \% \mathrm{Cl}$ : $43.18,276.01)$ in males, $55.85 \%$ (95\% Cl: $18.89,104.29)$ in females, $94.80 \%(95 \% \mathrm{Cl}: 22.35,210.16)$ in patients aged $18-59$ years, and $64.21 \%(95 \% \mathrm{Cl}: 26.01,114.00)$ in patients aged over 60 years. The effects of $\mathrm{PM}_{10}$ on the risk of severe COVID-19 were not significantly modified by sex or age $(P>0.05)$ (Table 4$)$.

Table 4

Changes in the risk of severe COVID-19 and their $95 \%$ Cls for a unit increase in $\mathrm{PM}_{10}$ concentration in subgroups, based on the single-pollutant models.

\begin{tabular}{|c|c|c|c|c|}
\hline Lag time & Male & Female & $18-59$ years old & $\geq 60$ years old \\
\hline $\begin{array}{l}\text { Lag 0-7 } \\
\text { days }\end{array}$ & $3.51(-8.59,17.21)$ & $\begin{array}{l}5.11(-5.99 \\
17.52)^{\mathrm{a}}\end{array}$ & $\begin{array}{l}11.16(-7.26 \\
33.23)\end{array}$ & $\begin{array}{l}0.84(-8.36 \\
10.96)^{\mathrm{a}}\end{array}$ \\
\hline $\begin{array}{l}\text { Lag 0-14 } \\
\text { days }\end{array}$ & $\begin{array}{l}86.82(32.53 \\
163.37)\end{array}$ & $\begin{array}{l}38.53(15.22 \\
66.55)^{\mathrm{a}}\end{array}$ & $\begin{array}{l}52.12(14.62 \\
101.88)\end{array}$ & $\begin{array}{l}47.30(21.83 \\
78.10)^{\mathrm{a}}\end{array}$ \\
\hline $\begin{array}{l}\text { Lag 0-21 } \\
\text { days }\end{array}$ & $\begin{array}{l}112.04(36.75 \\
228.79)\end{array}$ & $\begin{array}{l}50.08(17.63 \\
91.48)^{\mathrm{a}}\end{array}$ & $\begin{array}{l}89.84(17.49 \\
206.73)\end{array}$ & $\begin{array}{l}57.48(24.98 \\
98.41)^{\mathrm{a}}\end{array}$ \\
\hline $\begin{array}{l}\text { Lag 0-28 } \\
\text { days }\end{array}$ & $\begin{array}{l}132.03(43.18 \\
276.01)\end{array}$ & $\begin{array}{l}55.85(18.89 \\
104.29)^{\mathrm{a}}\end{array}$ & $\begin{array}{l}94.80(22.35 \\
210.16)\end{array}$ & $\begin{array}{l}64.21(26.01 \\
114.00)^{a}\end{array}$ \\
\hline
\end{tabular}

The associations between $\mathrm{PM}_{2.5}$ and the risk of severe COVID-19 remained significant in different gender or age groups at lag 0-14 days, lag 0-21 days, and lag 0-28 days. The maximum effect was observed at lag 0-28 days. For a unit increase in $\mathrm{PM}_{2.5}$, the risk of severe COVID-19 increased by $200.72 \%$ ( $95 \% \mathrm{Cl}$ : $58.61,470.16)$ in males, $109.13 \%(95 \% \mathrm{Cl}: 29.13,238.71)$ in females, $153.30 \%(95 \% \mathrm{Cl}: 25.43,411.54)$ in patients aged $18-59$ years, and $122.09 \%$ (95\% Cl: $40.50,251.05)$ in patients aged over 60 years. The effects of $\mathrm{PM}_{2.5}$ on the risk of severe COVID-19 were not significantly modified by sex or age $(P>0.05)$ (Table 5). 
Table 5

Changes in the risk of severe COVID-19 and their $95 \%$ Cls for a unit increase in $\mathrm{PM}_{2.5}$ concentration in subgroups, based on the single-pollutant models.

\begin{tabular}{|c|c|c|c|c|}
\hline Lag time & Male & Female & $18-59$ years old & $\geq 60$ years old \\
\hline $\begin{array}{l}\text { Lag 0-7 } \\
\text { days }\end{array}$ & $\begin{array}{l}-8.45(-25.26 \\
12.14)\end{array}$ & $\begin{array}{l}-5.55(-21.41 \\
13.50)^{\mathrm{a}}\end{array}$ & $\begin{array}{l}4.42(-19.88 \\
36.11)\end{array}$ & $\begin{array}{l}-12.42(-25.52, \\
2.98)^{\mathrm{a}}\end{array}$ \\
\hline $\begin{array}{l}\text { Lag 0-14 } \\
\text { days }\end{array}$ & $\begin{array}{l}65.83(15.08 \\
138.96)\end{array}$ & $\begin{array}{l}51.21(8.91 \\
109.93)^{a}\end{array}$ & $\begin{array}{l}48.62(5.38 \\
109.59)\end{array}$ & $\begin{array}{l}51.00(6.63 \\
113.83)^{\mathrm{a}}\end{array}$ \\
\hline $\begin{array}{l}\text { Lag 0-21 } \\
\text { days }\end{array}$ & $\begin{array}{l}156.15(46.81 \\
346.93)\end{array}$ & $\begin{array}{l}89.46(23.92 \\
189.66)^{a}\end{array}$ & $\begin{array}{l}125.06(22.24 \\
314.35)\end{array}$ & $\begin{array}{l}92.50(29.23 \\
186.73)^{\mathrm{a}}\end{array}$ \\
\hline $\begin{array}{l}\text { Lag 0-28 } \\
\text { days }\end{array}$ & $\begin{array}{l}200.72(58.61 \\
470.16)\end{array}$ & $\begin{array}{l}109.13(29.13 \\
238.71)^{\mathrm{a}}\end{array}$ & $\begin{array}{l}153.30(25.43 \\
411.54)\end{array}$ & $\begin{array}{l}122.09(40.50 \\
251.05)^{\mathrm{a}}\end{array}$ \\
\hline
\end{tabular}

\section{Discussion}

In this study, we conducted a time-series study among 476 COVID-19 patients caused by the Delta SARSCoV2 variant to explore the effects of short-term PM exposure on the risk of severe COVID-19. We observed that short-term exposure to PM was positively associated with the risk of severe COVID-19, and either sex or age did not alter the association. To our knowledge, this is the first individual-level study to evaluate the relationship between short-term PM exposure and the risk of severe COVID-19 in China.

A multicenter study in 33 European countries found that $\mathrm{PM}_{2.5}$ was positively related to the number of COVID-19 deaths [26]. Although this study was qualitative and did not consider potential confounding factors, it provided evidence of PM exposure contributing to a poor prognosis of COVID-19. A global research based on satellite data showed that approximately $15 \%$ of the global COVID- 19 mortality ( $27 \%$ in East Asia, $19 \%$ in Europe, and $17 \%$ in North America) were attributed to the long-term $\mathrm{PM}_{2.5}$ exposure [27]. A study in California reported that a wildfire increased the $\mathrm{PM}_{2.5}$ concentration in ten counties by $220.71 \%$, and subsequently, the number of deaths from COVID-19 in these areas increased by $148.2 \%$ [28]. Another study in London showed that environmental $\mathrm{PM}_{2.5}$ was positively correlated with the mortality of COVID-19. For a unit increase in $\mathrm{PM}_{2.5}$, the number of deaths due to COVID-19 increased by $2.3 \%$ [29]. Another study explored the relationships between long-term exposure to $\mathrm{PM}_{2.5}$ and the hospitalization of COVID-19 in Cincinnati and found that a unit increase in 10-year average $\mathrm{PM}_{2.5}$ concentration was correlated with an $18 \%$ higher hospitalization rate [30]. Although most of the previous studies were ecological and focused on the COVID-19 mortality or hospitalization rate, their findings indirectly supported that PM exposure was related to the severity of COVID-19. Moreover, our results showed that the effect of $\mathrm{PM}_{2.5}$ seemed to be stronger than $\mathrm{PM}_{10}$. This may be attributed to the smaller 
particle size of $\mathrm{PM}_{2.5}$, which can penetrate deep into the alveoli and bronchioles, and thus has more potent biological toxicity [11].

The following reasons may explain the potential links between PM and severe COVID-19. Firstly, PM suspended in the air, especially for $\mathrm{PM}_{2.5}$, may not only carry the SARS-CoV-2, but also enhance the attachment and replication of the virus in the bronchus by damaging the integrity of bronchial epithelial cells [30]. Secondly, as pointed by Domingo et al., SARS-CoV-2 attached to PM may survive longer and be more aggressive in the immune system, which was aggravated by exposure to high concentrations of air pollutants [31]. Thirdly, as mentioned before, $\mathrm{PM}_{2.5}$ can reach the alveoli, thereby delivering the SARSCoV-2 to the target type II alveolar cells [30]. Previous studies have shown that PM, especially $\mathrm{PM}_{2.5}$, can stimulate activated alveolar macrophages and then induce pro-inflammatory cytokines production and release, thus aggravating the allergic inflammation in the lungs [32]. Fourthly, the metals and polycyclic aromatic hydrocarbons that make up $\mathrm{PM}_{2.5}$ facilitate the production of free radicals, which may oxidize alveolar cells. Excessive free radicals would weaken cellular antioxidant capacity, leading to lipid peroxidation and increased intracellular calcium concentration, further inducing cellular damage [33]. Finally, the SARS-CoV-2 entered the cell through binding to the angiotensin-converting enzyme 2 (ACE2) receptor, and this process can be enhanced by PM exposure [13]. The binding of the SARS-CoV-2 and the ACE2 receptor resulted in the down-regulation of the latter. The ACE2 mediated the transformation of angiotensin II to angiotensin 1-7 through the G protein-coupled receptor pathway and worked with angiotensin 1-7 by anti-inflammatory and antioxidant to protect the body. The down-regulation of ACE2 decreased its protective effect and worsened the effect of angiotensin II [34].

Our study had several limitations. First, we estimated the PM exposure level of each patient based on the monitoring data from the fixed sites, which may not accurately reflect the individual exposure. Second, other factors related to the severity of COVID-19, which were not considered in the analysis, may affect the results. Third, since the epidemic was under control for a short time, the sample size of this study was relatively small, especially for the number of severe patients. The association between PM and severe COVID-19 needs to be further confirmed in future studies.

\section{Conclusions}

Our results showed that short-term PM exposure was positively correlated with the risk of severe COVID19 , and such an association was not significantly altered by sex or age. Curbing outdoor PM pollution will help decrease the burden of COVID-19 and benefit the prognosis.

\section{Abbreviations}

COVID-19

Corona Virus Disease 2019

GLM

generalized linear model 
PM

particulate matter

$\mathrm{Cl}$

confidence interval

ACE2

angiotensin-converting enzyme 2 .

\section{Declarations}

\section{Acknowledgements}

Not applicable.

\section{Authors' contributions}

ZL, BT, and JW conceived, initiated, and led the study. ZL, BT, MZ, ZH, and YY collected the data. ZL, BT, and JW analyzed the data with input from all the authors. ZL and JW prepared the manuscript. All authors reviewed and approved the manuscript.

\section{Funding}

This study was funded by the National Natural Science Foundation of China (81973103), Medical Research Project of Jiangsu Health Commission (ZDB2020013), Key Project of Philosophy and Social Science Research in Colleges and Universities in Jiangsu Province (2020SJZDA096), and Priority Academic Program Development of Jiangsu Higher Education Institutions (PAPD). The funding agencies had no role in the study design, data collection, analysis, decision to publish, or preparation of the manuscript.

\section{Availability of data and materials}

Please contact the author for the original data.

\section{Ethics approval and consent to participate}

This study was approved by the Ethics Committee of Nanjing Public Health Medical Center.

\section{Consent for publication}

Not applicable.

\section{Competing interests}

The authors declare that they have no known competing financial interests or personal relationships that could have influenced the work reported in this paper. 


\section{Author details}

${ }^{1}$ Department of Epidemiology, Center for Global Health, School of Public Health, Nanjing Medical University, Nanjing, 211166 China.

${ }^{2}$ Nanjing Public Health Medical Center, the Second Hospital of Nanjing, Nanjing University of Chinese Medicine, Nanjing, 210003 China.

\section{References}

1. Zhu N, Zhang D, Wang W, Li X, Yang B, Song J, et al. A Novel Coronavirus from Patients with Pneumonia in China, 2019. N Engl J Med. 2020;382(8):727-733. https://doi.org/10.1056/NEJMoa2001017.

2. Novelli G, Biancolella M, Mehrian-Shai R, Erickson C, Godri Pollitt KJ, Vasiliou V, et al. COVID-19 update: the first 6 months of the pandemic. Hum Genomics. 2020;14(1):48. https://doi.org/10.1186/s40246-020-00298-w.

3. Zhang J, Wang X, Jia X, Li J, Hu K, Chen G, et al. Risk factors for disease severity, unimprovement, and mortality in COVID-19 patients in Wuhan, China. Clin Microbiol Infect. 2020;26(6):767-772. https://doi.org/10.1016/j.cmi.2020.04.012.

4. Li X, Xu S, Yu M, Wang K, Tao Y, Zhou Y, et al. Risk factors for severity and mortality in adult COVID19 inpatients in Wuhan. J Allergy Clin Immunol. 2020;146(1):110-118. https://doi.org/10.1016/j.jaci.2020.04.006.

5. Croft DP, Zhang W, Lin S, Thurston SW, Hopke PK, van Wijngaarden E, et al. Associations between Source-Specific Particulate Matter and Respiratory Infections in New York State Adults. Environ Sci Technol. 2020;54(2):975-984. https://doi.org/10.1021/acs.est.9b04295.

6. Wu W, Jin Y, Carlsten C. Inflammatory health effects of indoor and outdoor particulate matter. J Allergy Clin Immunol. 2018;141(3):833-844. https://doi.org/10.1016/j.jaci.2017.12.981.

7. Prabhakaran D, Mandal S, Krishna B, Magsumbol M, Singh K, Tandon N, et al. Exposure to Particulate Matter Is Associated With Elevated Blood Pressure and Incident Hypertension in Urban India. Hypertension. 2020;76(4):1289-1298. https://doi.org/10.1161/hypertensionaha.120.15373.

8. Yao L, LiangLiang C, JinYue L, WanMei S, Lili S, YiFan L, et al. Ambient air pollution exposures and risk of drug-resistant tuberculosis. Environ Int. 2019;124(161-169. https://doi.org/10.1016/j.envint.2019.01.013.

9. Landguth EL, Holden ZA, Graham J, Stark B, Mokhtari EB, Kaleczyc E, et al. The delayed effect of wildfire season particulate matter on subsequent influenza season in a mountain west region of the USA. Environ Int. 2020;139(105668. https://doi.org/10.1016/j.envint.2020.105668.

10. Matsuo R, Michikawa T, Ueda K, Ago T, Nitta H, Kitazono T, et al. Short-Term Exposure to Fine Particulate Matter and Risk of Ischemic Stroke. Stroke. 2016;47(12):3032-3034. https://doi.org/10.1161/strokeaha.116.015303. 
11. Liu C, Chen R, Sera F, Vicedo-Cabrera AM, Guo Y, Tong S, et al. Ambient Particulate Air Pollution and Daily Mortality in 652 Cities. N Engl J Med. 2019;381(8):705-715. https://doi.org/10.1056/NEJMoa1817364.

12. Zoran MA, Savastru RS, Savastru DM, Tautan MN. Assessing the relationship between surface levels of PM2.5 and PM10 particulate matter impact on COVID-19 in Milan, Italy. Sci Total Environ. 2020;738(139825. https://doi.org/10.1016/j.scitotenv.2020.139825.

13. Tung NT, Cheng PC, Chi KH, Hsiao TC, Jones T, BéruBé K, et al. Particulate matter and SARS-CoV-2: A possible model of COVID-19 transmission. Sci Total Environ. 2021;750(141532. https://doi.org/10.1016/j.scitotenv.2020.141532.

14. Wang B, Liu J, Li Y, Fu S, Xu X, Li L, et al. Airborne particulate matter, population mobility and COVID19: a multi-city study in China. BMC Public Health. 2020;20(1):1585.

https://doi.org/10.1186/s12889-020-09669-3.

15. Prinz AL, Richter DJ. Long-term exposure to fine particulate matter air pollution: An ecological study of its effect on COVID-19 cases and fatality in Germany. Environ Res. 2021;204(Pt A):111948. https://doi.org/10.1016/j.envres.2021.111948.

16. Cherian S, Potdar V, Jadhav S, Yadav P, Gupta N, Das M, et al. SARS-CoV-2 Spike Mutations, L452R, T478K, E484Q and P681R, in the Second Wave of COVID-19 in Maharashtra, India. Microorganisms. 2021;9(7):https://doi.org/10.3390/microorganisms9071542.

17. Kang M, Yi Y, Li Y, Sun L, Deng A, Hu T, et al. Effectiveness of inactivated COVID-19 vaccines against COVID-19 pneumonia and severe illness caused by the B. 1.617. 2 (Delta) variant: evidence from an outbreak in Guangdong, China. Available at SSRN: https://ssrncom/abstract=3895639. 2021;https

18. Liu C, Yin P, Chen R, Meng X, Wang L, Niu Y, et al. Ambient carbon monoxide and cardiovascular mortality: a nationwide time-series analysis in 272 cities in China. Lancet Planet Health. 2018;2(1):e12-e18. https://doi.org/10.1016/s2542-5196(17)30181-x.

19. Du W, Zhang W, Hu H, Zhang M, He Y, Li Z. Associations between ambient air pollution and hospitalizations for acute exacerbation of chronic obstructive pulmonary disease in Jinhua, 2019. Chemosphere. 2021;267(128905. https://doi.org/10.1016/j.chemosphere.2020.128905.

20. Chen R, Yin P, Meng X, Liu C, Wang L, Xu X, et al. Fine Particulate Air Pollution and Daily Mortality. A Nationwide Analysis in 272 Chinese Cities. Am J Respir Crit Care Med. 2017;196(1):73-81. https://doi.org/10.1164/rccm.201609-18620C.

21. You S, Tong YW, Neoh KG, Dai Y, Wang CH. On the association between outdoor PM(2.5) concentration and the seasonality of tuberculosis for Beijing and Hong Kong. Environ Pollut. 2016;218(1170-1179. https://doi.org/10.1016/j.envpol.2016.08.071.

22. Zhu Y, Xie J, Huang F, Cao L. Association between short-term exposure to air pollution and COVID-19 infection: Evidence from China. Sci Total Environ. 2020;727(138704.

https://doi.org/10.1016/j.scitotenv.2020.138704.

23. Xie J, Zhu Y. Association between ambient temperature and COVID-19 infection in 122 cities from China. Sci Total Environ. 2020;724(138201. https://doi.org/10.1016/j.scitotenv.2020.138201. 
24. Zhu S, Xia L, Wu J, Chen S, Chen F, Zeng F, et al. Ambient air pollutants are associated with newly diagnosed tuberculosis: A time-series study in Chengdu, China. Sci Total Environ. 2018;631-632(4755. https://doi.org/10.1016/j.scitotenv.2018.03.017.

25. Zheng S, Zhu W, Wang M, Shi Q, Luo Y, Miao Q, et al. The effect of diurnal temperature range on blood pressure among 46,609 people in Northwestern China. Sci Total Environ. 2020;730(138987. https://doi.org/10.1016/j.scitotenv.2020.138987.

26. Lembo R, Landoni G, Cianfanelli L, Frontera A. Air pollutants and SARS-CoV-2 in 33 European countries. Acta Biomed. 2021;92(1):e2021166. https://doi.org/10.23750/abm.v92i1.11155.

27. Pozzer A, Dominici F, Haines A, Witt C, Münzel T, Lelieveld J. Regional and global contributions of air pollution to risk of death from COVID-19. Cardiovasc Res. 2020;116(14):2247-2253. https://doi.org/10.1093/cvr/cvaa288.

28. Meo SA, Abukhalaf AA, Alomar AA, Alessa OM, Sami W, Klonoff DC. Effect of environmental pollutants PM-2.5, carbon monoxide, and ozone on the incidence and mortality of SARS-COV-2 infection in ten wildfire affected counties in California. Sci Total Environ. 2021;757(143948. https://doi.org/10.1016/j.scitotenv.2020.143948.

29. Meo SA, Adnan Abukhalaf A, Sami W, Hoang TD. Effect of environmental pollution PM2.5, carbon monoxide, and ozone on the incidence and mortality due to SARS-CoV-2 infection in London, United Kingdom. J King Saud Univ Sci. 2021;33(3):101373. https://doi.org/10.1016/j.jksus.2021.101373.

30. Mendy A, Wu X, Keller JL, Fassler CS, Apewokin S, Mersha TB, et al. Air pollution and the pandemic: Long-term PM(2.5) exposure and disease severity in COVID-19 patients. Respirology. 2021;https://doi.org/10.1111/resp.14140.

31. Domingo JL, Rovira J. Effects of air pollutants on the transmission and severity of respiratory viral infections. Environ Res. 2020;187(109650. https://doi.org/10.1016/j.envres.2020.109650.

32. Manivannan J, Sundaresan L. Systems level insights into the impact of airborne exposure on SARSCoV-2 pathogenesis and COVID-19 outcome - A multi-omics big data study. Gene Rep. 2021;25(101312. https://doi.org/10.1016/j.genrep.2021.101312.

33. Xing YF, Xu YH, Shi MH, Lian YX. The impact of PM2.5 on the human respiratory system. J Thorac Dis. 2016;8(1):E69-74. https://doi.org/10.3978/j.issn.2072-1439.2016.01.19.

34. Zhu C, Maharajan K, Liu K, Zhang Y. Role of atmospheric particulate matter exposure in COVID-19 and other health risks in human: A review. Environ Res. 2021;198(111281. https://doi.org/10.1016/j.envres.2021.111281.

\section{Figures}




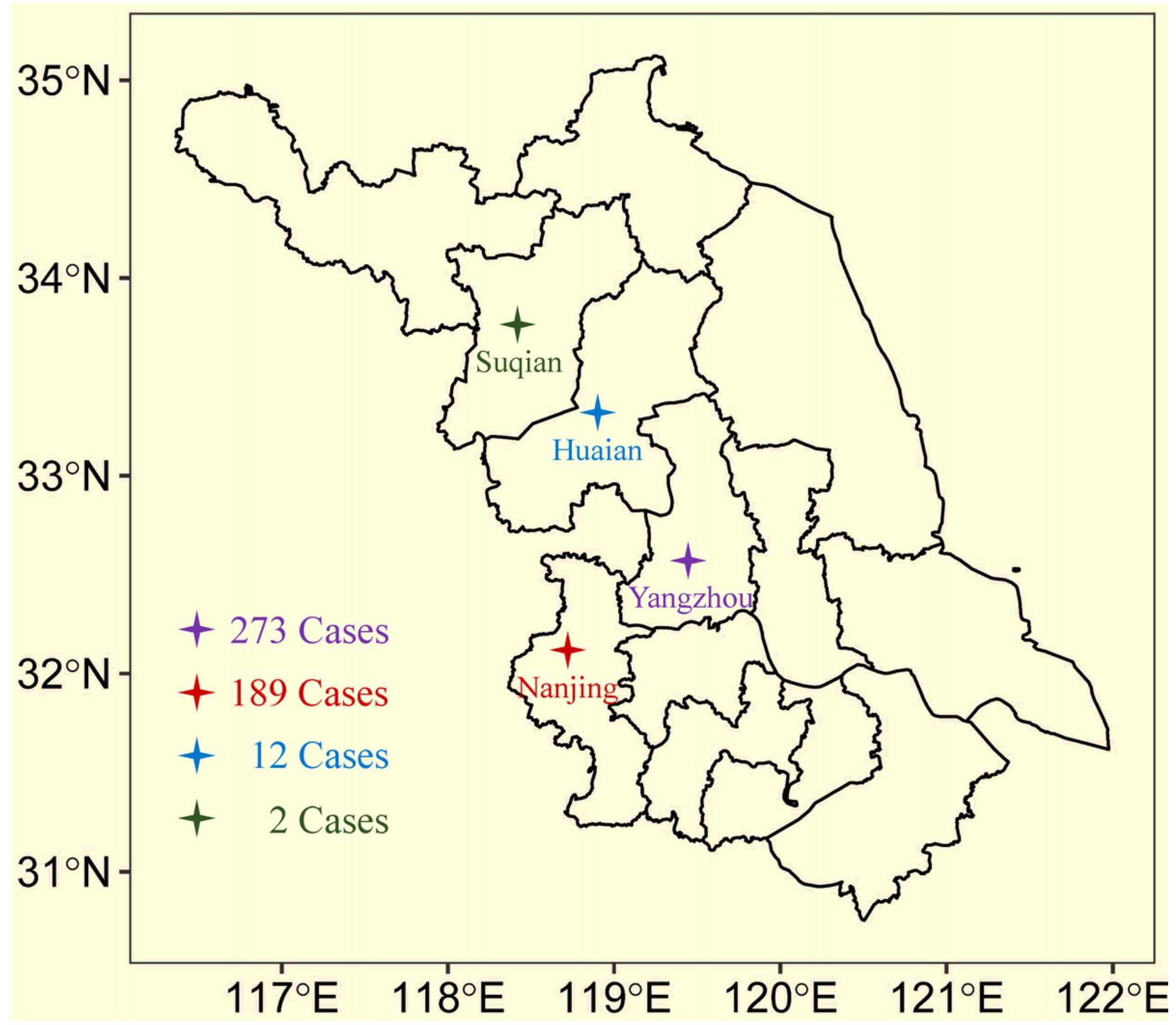

Figure 1

The geographic location of the four cities in Jiangsu Province. 